\title{
Efektifitas Pembayangan yang Dihasilkan Pohon dan Bangunan di Koridor Jalan Perkotaan Untuk Mencapai Kenyamanan Termal
}

\author{
Jockie Zudhy Fibrianto', Mochamad Hilmy ${ }^{1}$ \\ ${ }_{1}^{1}$ Politeknik Negeri Pontianak, Pontianak, Indonesia \\ joxxxie@gmail.com \\ doi.org/ 10.29080/emara.v4i1.177
}

\begin{abstract}
The road corridor in Pontianak City has different shading output depending on the sun orientation. The difference has caused a temperature difference that affects the pedestrian thermal comfort along the corridor. Identification and measurement of shading temperatures that occur due to buildings and trees were carried out for three days in each afternoon with relatively similar weather conditions. The road corridor that becomes the research location was at A. Yani St.-Gajah Mada St.-Tanjung Pura St., which has a North-South orientation and Teuku Umar St.-Diponegoro St.-Sisingamangaraja St., who has an East-West direction. The analysis phase is done by comparing the effectiveness of imagery produced by buildings and trees. After that, the identification and measurement results are compared with Indonesian thermal comfort standards SNI T-14-1993-03 to obtain suitable thermal comfort in the road corridors in Pontianak City.
\end{abstract}

Keywords: thermal comfort, road corridors, shading

\begin{abstract}
Abstrak: Koridor jalan di Kota Pontianak memiliki output pembayangan yang berbeda-beda tergantung kepada orientasi matahari.Perbedaan tersebut telah menimbulkan perbedaan temperatur yang berdampak pada kenyamanan termal pengguna jalan disepanjang koridor. Identifikasi dan pengukuran temperatur pembayangan yang terjadi akibat bangunan dan pohon dilakukan selama tiga hari pada setiap sore dengan kondisi cuaca yang relatif sama.Koridor jalan yang menjadi lokasi penelitian yaitu JI.A.Yani-JI.Gajah Mada-JI.Tanjung Pura, yang memiliki orientasi Utara-Selatan serta koridor JI.Teuku Umar-JI.Diponegoro-JI.Sisingamangaraja yang memiliki orientasi Timur-Barat. Tahapan analisa dilakukan dengan mengkomparasi efektifitas pembayangan yang dihasilkan oleh bangunan dan pohon. Setelah itu hasil identifikasi dan pengukuran dibandingkan dengan Standar kenyamanan termal Indonesia SNI T-14-1993-03 untuk mendapatkan kenyamanan termal yang sesuai pada koridor jalan di Kota Pontianak.
\end{abstract}

Kata Kunci: kenyamanan termal, koridor jalan, pembayangan

\section{PENDAHULUAN}

Suhu udara adalah keadaan panas udara yang di sebabkan oleh panas matahari. Faktor-faktor yang mempengaruhi banyak sedikitnya panas matahari yang di terima oleh bumi adalah keadaan awan, keadaan bidang permukaan, sudut sinar datang, dan lamanya penyinaran matahari. Panas permukaan bumi oleh penyinaran matahari mempengaruhi panas udara. Suhu udara di permukaan bumi bervariasi karena sinar matahari menyebar tidak merata di permukaan bumi.

Kota Pontianak merupakan salah satu kota yang dilalui oleh garis khatulistiwa yang berdampak pada cukup tingginya temperatur. Pada pusat kota hampir sebagian besar mengggunakan penutup lahan jalan yaitu dengan aspal dan beton, kondisi tersebut berdampak terhadap tingginya temperatur pada suatu area pada saat terkena sinar matahari. Koridor jalan di pusat Kota Pontianak yang sebagian besar tertutupi oleh aspal memiliki temperatur yang tinggi pada saat terkena sinar matahari langsung, kondisi ini tentunya berdampak pada kenyamanan termal pada koridor tersebut bagi pengguna jalan.

Dengan adanya pembayangan yang dihasilkan oleh pohon dan juga bangunan tentunya akan mengurangi tingginya tenperatur yang tercipta di koridor jalan. Pembayangan yang dihasilkan oleh pepohonan dan bangunan tentunya memiliki karakteristik yang berbeda yang nantinya akan menghasilkan nilai temperatur yang berbeda juga. Koridor jalan yang 
berada di pusat Kota Pontianak memiliki morfologi yang berbeda-beda, dimana terdapat koridor yang hanya terdiri bangunan tinggi sehingga terjadi pembayangan yang dihasilkan oleh bangunan pada waktu tertentu terhadap jalan dan juga terdapat koridor yang ternaungi oleh pohon.

Berdasarkan kondisi diatas maka dilakukan perbandingan antara pembayangan yang dihasilkan oleh bangunan dan pembayangan yang dihasilkan oleh pohon dengan melakukan pengukuran temperatur, sehingga didapat efektifitasnya dengan tujuan untuk kenyamanan termal bagi pengguna jalan dan lingkungan pada koridor jalan.

Kondisi koridor jalan pada pusat Kota Pontianak yang memiliki karakteristik yang berbeda terhadap orientasi matahari, menjadi permasalahan utama karena tercipta pembayangan yang berbeda-beda khususnya yang dihasilkan oleh bangunan dan pohon. Koridor yang diamati yaitu koridor pada : Jl. A. Yani Jl. Gajah Mada - Jl. Tanjung Pura, dan koridor Jl. Teuku Umar - Jl. Diponegoro - Jl. Sisingamangaraja.

Selain itu pantulan dan penyerapan serta radiasi matahari sebagai faktor yang mempengaruhi kenyamanan termal (Lippsmeier, 1994). Penciptaan kenyamanan termal, diketahui ada enam faktor yang mempengaruhi kemampuan tubuh manusia menyalurkan kalor (Auliciems, Andris, \& V., 2007), yaitu: rata-rata metabolisme tubuh (M), Net radiation $(\mathrm{R})$, pelepasan panas (E), Convectionl (Cv), Conductionl $(\mathrm{Cd})$ dan perubahan suhu badan $(\Delta \mathrm{S})$, dengan persamaan sebagai berikut:

\section{$\mathrm{M} \pm \mathrm{R} \pm \mathrm{C} v \pm \mathrm{Cd}-\mathrm{E}=\Delta \mathrm{S}(\mathrm{W})$}

Faktor-faktor kenyamanan termal dikelompokkan menjadi 3 yaitu lingkungan, personal dan faktor kontribusi. Lingkungan yang mempengaruhi terdiri dari suhu udara, pergerakan udara, kelembaban dan radiasi. Personal yang mempengaruhi terdiri dari ratarata metabolisme dan pakaian yang dikenakan. Faktor kontribusi yang mempengaruhi adalah makanan dan minuman, luas permukaan badan, usia dan jenis kelamin, kondisi kesehatan tubuh, kemampuan beradaptasi dengan lingkungan dan lemak di bawah kulit (Auliciems, Andris, \& V., 2007).

Dalam studi kenyamanan termal para peneliti sepakat dengan enam variabel penentu kenyamanan termal. Dua variabel personal pakaian dan aktivitas dan empat variabel iklim suhu udara, suhu radiasi permukaan bidang, kecepatan angin dan kelembaban udara (Sugini, 2004). Kenyamanan yang paling dominan pengaruhnya terhadap kenyamanan fisik manusia yang berada dalam bangunan adalah kenyamanan termal, meliputi: temperatur udara, kelembaban dan kecepatan aliran udara (Baharuddin, M.Taufik, Syarif, \& M.Yoenus, 2013). Kenyaman termal daerah tropis lembab dapat dicapai dengan batas- batas $24^{\circ} \mathrm{C}<\mathrm{T}<26^{\circ} \mathrm{C}, 40 \%<\mathrm{RH}<60 \%, 0,6<\mathrm{V}<$ $1,5 \mathrm{~m} /$ det, kegiatan santai, pakaian ringan dan selapis (Satwiko \& Prasasto, 2008).

Untuk menentukan temperatur dasar atau temperatur referensi, maka penelitian ini mengacu pada Standar kenyaman termal Indonesia SNI T-141993-03 yang terdiri dari tiga katagori, yakni:

1) Sejuk nyaman, $20,5^{\circ} \mathrm{C}-22,8^{\circ} \mathrm{C}$, kelembaban relatif $50 \%-80 \%$.

2) Nyaman optimal $22,8^{\circ} \mathrm{C}-25,8^{\circ} \mathrm{C}$, kelembaban relatif $70 \%-80 \%$

3) Hampir nyaman $25,8^{\circ} \mathrm{C}-27,1^{\circ} \mathrm{C}$, kelembaban relatif $60 \%-70 \%$.

Menurut Nikolopoulou dan Lykoudis (2006), jalan merupakan salah satu faktor pengaruh kenyamanan termal suatu bangunan di sekitarnya terhadap sinar matahari, baik itu yang langsung maupun yang terpantulkan, juga terhadap gerakan angin.

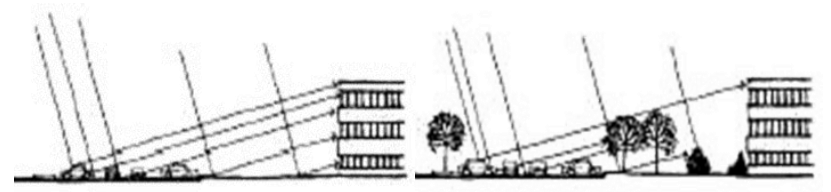

(a)
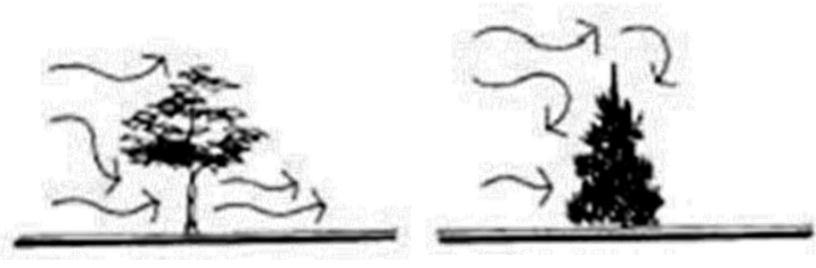

(b)

Gambar 1. Kenyamanan termal yang timbul dari (a) sinar matahari dan (b) gerakan angin. (sumber: Nikolopoulou \& Lykoudis, 2006)

Faktor-faktor penyebab timbul atau tidaknya kenyamanan termal seperti jalan dapat memberikan dampak timbul atau tidaknya kenyamanan termal pada bangunan yang terkena pantulan matahari (yang langsung maupun yang tidak langsung) dan terkena aliran angin (Nikolopoulou \& Lykoudis, 2006). Juga memberikan pengaruh terhadap kenyamanan termal lingkungan disekitarnya.

\section{METODE PENELITIAN}

Metode penelitian yang akan diaplikasikan yaitu terdiri dari beberapa tahapan yaitu :

a. Studi literatur, input data dan teori terkait pembayangan dan kenyamanan termal, serta data peta koridor jalan (JI. Gajah Mada - Jl. Tanjung Pura - Jl. A. Yani, dan JI. Diponegoro - Jl. Agus Salim - Jl. Sisingamangaraja)

b. Identifikasi temperatur koridor jalan, yaitu dengan melakukan pengukuran temperatur pembayangan bangunan dan pohon pada koridor jalan (Jl. Gajah 
Mada - Jl. Tanjung Pura - Jl. A. Yani, dan Jl. Diponegoro - Jl. Agus Salim - Jl. Sisingamangaraja) dengan interval setiap waktu 2 (dua) jam dalam 1 (satu) hari selama 3 (tiga) hari berturut-turut.

c. Analisa, dengan membandingkan antara hasil pengukuran pada area terbayangi bangunan dan pohon di setiap koridor.

d. Hipotesa, menyimpulkan hasil dari analisa terhadap kenyamanan termal.

\section{HASIL DAN PEMBAHASAN}

\subsection{Pengukuran pada koridor jalan terpilih}

Pengaruh pembayangan massa bangunan terhadap radiasi panas matahari pernah dilakukan pengkajian di ruang terbuka kawasan tropis yang terletak pada garis lintang $7^{\circ} \mathrm{LS}$, dengan metode simulasi komputer dan dari kajian tersebut menyatakan orientasi bangunan terhadap lintasan sinar matahari sangat mempengaruhi hasil dari pembayangan yang terbentuk (Dotulong, 2008). Bentuk bangunan mempengaruhi pembayangan yang terbentuk dikarenakan penyinaran panas matahari yang terhalang oleh bentuk bangunan itu sendiri (Indraswara \& Rifan, 2013).

Kajian literatur yang digunakan terkait dengan pembayangan yang dihasilkan oleh bangunan dan pohon khususnya pada koridor jalan, dengan menggunakan metode identifikasi berupa pengukuran temperatur pada koridor jalan dan kajian literatur terkait dengan kenyamanan termal bagi pengguna jalan khususnya bagi pedestrian pada koridor jalan mengacu pada standar kenyaman termal Indonesia SNI T-14-1993-03. Diskusi internal bersama tim juga dilakukan baik dalam persiapan untuk dilakukannya survey ke lokasi yang telah direncanakan dan juga dalam penyusunan metode identifikasi pengukuran temperatur. Diskusi internal ini juga membahas lokasi koridor yang akan di survey melalui peta Kota Pontianak.

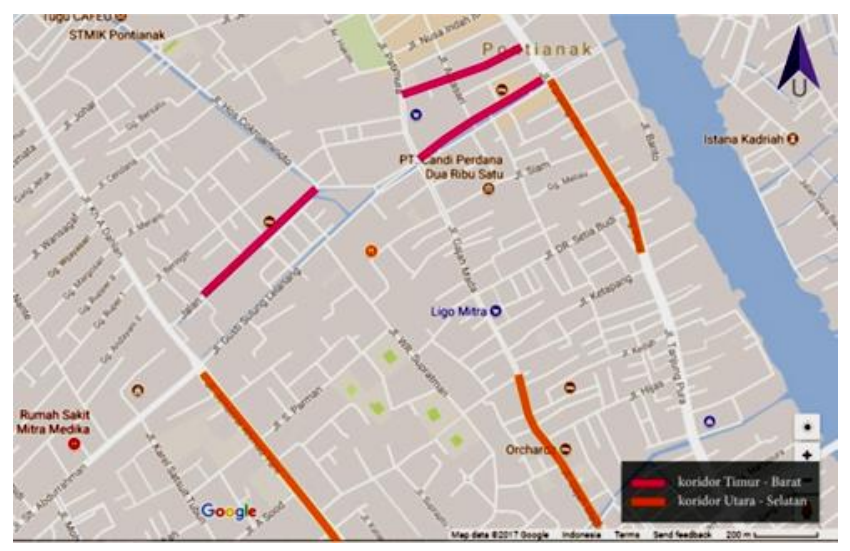

Gambar 2. Peta koridor jalan berdasarkan orientasi (sumber : hasil analisis, 2017)
Tahapan survey dilakukan sebelum dilakukannya pengukuran untuk mengetahui karakter pembayangan pada koridor jalan di Kota Pontianak yang dihasilkan oleh bangunan dan oleh pohon. Berdasarkan hasil dari diskusi internal pada tahapan sebelumnya, maka disepakati 3 (tiga) koridor Utara-Selatan dan 3 (tiga) koridor Timur-Barat terhadap arah Utara pada peta Kota Pontianak sebagai lokus dalam penelitian ini yang menjadi perwakilan bagi koridor di Kota Pontianak (gambar 2). Koridor Utara-Selatan yaitu : koridor jalan Teuku Umar, jalan Diponegoro, dan jalan Sisingamangaraja, serta koridor Timur-Barat yaitu koridor jalan. A. Yani, jalan Gajah Mada, dan jalan Tanjung Pura. Setiap kelompok koridor terdapat 1 (satu) koridor yang memiliki karakter dengan pembayangan pohon yaitu jalan Diponegoro dan jalan A.Yani, sedangkan koridor lainnya dengan karakter pembayangan oleh bangunan.

\subsection{Identifikasi pengukuran temperatur pada koridor jalan}

Pengukuran temperatur udara dilakukan pada beberapa koridor jalan di Kota Pontianak. Beberapa tipe koridor jalan dipilih berdasar karakter lalu lintas yang mendekati sama, yaitu dari kuantitas kendaraan yang melaluinya serta dimensi jalan yang mendekati meskipun ada 1 (satu) koridor jalan yang lalu lintasnya tidak sepadat jalan lainnya. Dari koridor jalan yang ada di Kota Pontianak, dipilihlah koridor jalan yang memiliki orientasi mendekati sejajar arah lintasan matahari dan juga koridor jalan dengan orientasi mendekati melintang arah lintasan matahari. Berdasarkan kajian yang dilakukan, maka di koridor jalan tersebut dipilih beberapa titik yang mengalami pembayangan dari vegetasi atau bangunan.

Dari pengukuran di lapangan, diperoleh data temperatur udara dan permukaan material perkerasan.yang ada, pada kasus ini perkerasan di jalur pedestrian. Berdasarkan kondisi yang memungkinkan dilakukan pengukuran, terpilihlah 4 titik lokasi pengukuran untuk koridor Utara-Selatan, yaitu 2 titik di Jl. Ahmad Yani, 1 titik di Jl. Gajah Mada, dan 1 titik di Jl. Tanjung Pura. Titik pengukuran ke 4 memiliki rerata temperatur terendah dibandingkan dengan titik yang lain. Jika ditelaah kondisi yang terjadi di lapangan, daerah tersebut terbayangi oleh bangunan gedung pada pagi hari dan sore hari, karena jalan tersebut agak menyerong. Selain titik tersebut, pada titik 3 juga dinaungi oleh pembayangan bangunan gedung di pagi dan sore hari, radiasi matahari hanya mengenai titik pengukuran pada siang hari, sedangkan pada pagi hingga siang hari titik pengukuran tersebut terkena radiasi panas matahari 


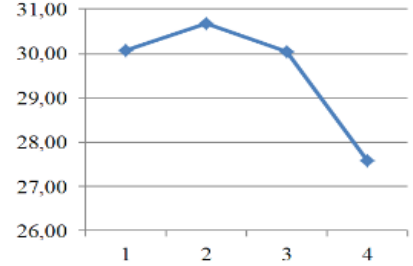

(a)

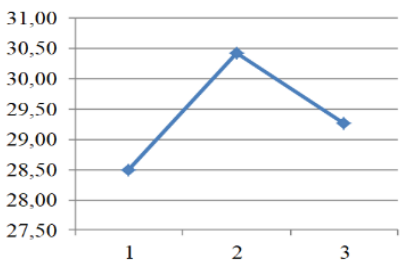

(b)
Gambar 3. Hasil pengukuran temperatur udara pada (a) Koridor Jalan Utara-Selatan dan (b) Koridor Jalan Timur-Barat (sumber: hasil analisa, 2017)

Pada titik 1, pembayangan dihasilkan oleh vegetasi pada pagi hari dan siang hari, sedangkan pada sore hari terkena sinar matahari. Sedangkan pada titik ke 2, pembayangan terjadi pada siang hari dan sore hari. Temperatur udara di titik 1 dan 2 memiliki temperatur yang relatif tinggi kemungkinan dipengaruhi oleh lebar ruas jalan yang paling lebar dibandingkan ruas jalan yang lain.

Pengukuran juga dilakukan di ruas jalan yang mendekati terhadap arah lintasan matahari, meliputi JI. Teuku Umar, JI. Diponegoro dan JI. Sisingamangaraja. Titik pengukuran yang dipilih masing masing diwakili 1 titik. Temperatur terendah yang didapatkan berdasarkan pengukuran lapangan terjadi pada titik pengukuran ke 1 . Kondisi lokasi pengukuran tersebut adalah koridor jalan tersebut ternaungi sepenuhnya pada pagi dan menjelang sore hari hingga terbenamnya matahari. Pembayangan terjadi sepenuhnya oleh bangunan gedung yang menjulang tinggi, karena posisi koridor jalan tersebut agak menyerong dari arah lintasan matahari dan titik pengukuran merupakan area yang terbayangi.

Kondisi titik ke 2 adalah terjadi pembayangan oleh vegetasi. Pembayangan terjadi hanya pada sore hari. Titik pengukuran tersebut posisinya sangat dekat dengan persimpangan jalan raya dengan tingkat kepadatan lalu lintas yang tinggi. Titik pengukuran ke 3 berada di jalur pedestrian yang dinaungi oleh bangunan gedung di pagi hingga menjelang siang hari dan siang menjelang sore hingga matahari terbenam. Koridor jalan ini relatif paling kecil dan dan memiliki intensitas lalu lintas kendaraan bermotor yang tidak sepadat 2 jalan lainnya.

\subsection{Temperatur permukaan material di jalur pedestrian koridor jalan di kota Pontianak}

Semua jalan yang dilakukan pengukuran temperatur menggunakan aspal sebagai penutup permukaannya. Tingkat lalu lintas kendaraan bermotor yang terjadi juga mendekati sama yaitu padat lancar. Lokasi pengukuran juga dipilih di pusat kota yang memiliki jalur pedestrian dan memiliki kepadatan bangunan yang tinggi. Material penutup permukaan jalur pedestrian terdapat 2 perbedaan material yaitu penggunaan paving block dan rabat beton. Namun penggunaan paving hanya terdapat di koridor Jl. Ahmad Yani, dalam hal ini diberikan kode pengukuran 1 dan 2. Hasil pengukuran temperatur permukaan terlihat pada gambar 4 .

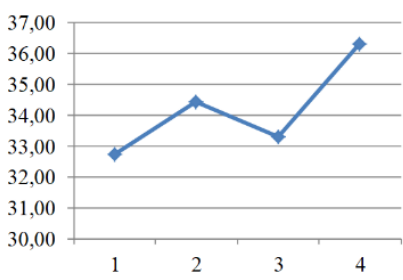

(a)

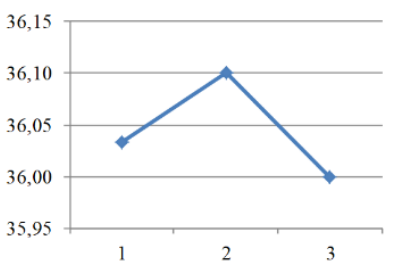

(b)
Gambar 3. Hasil pengukuran temperatur permukaan pada (a) Koridor Jalan Utara-Selatan dan (b) Koridor Jalan Timur-Barat (sumber: hasil analisa, 2017).

\subsection{Analisa pengaruh jenis pembayangan dan material permukaan jalur pedestrian terhadap temperatur udara jalur pedestrian koridor jalan di Kota Pontianak}

Koridor jalan yang mendekati arah Utara-Selatan merupakan koridor jalan yang memotong arah lintasan matahari. Koridor jalan yang lebar menjadikan sebagian besar koridor jalan tersebut terpapar oleh radiasi sinar matahari terutama pada siang hari. Pembayangan terjadi kemungkinan hanya pada jalur pedestrian atau badan jalan yang ternaungi oleh penghijauan kota dan terbantukan oleh posisi koridor jalan yang agak menyerong sehingga membentuk area pembayangan lebih luas.

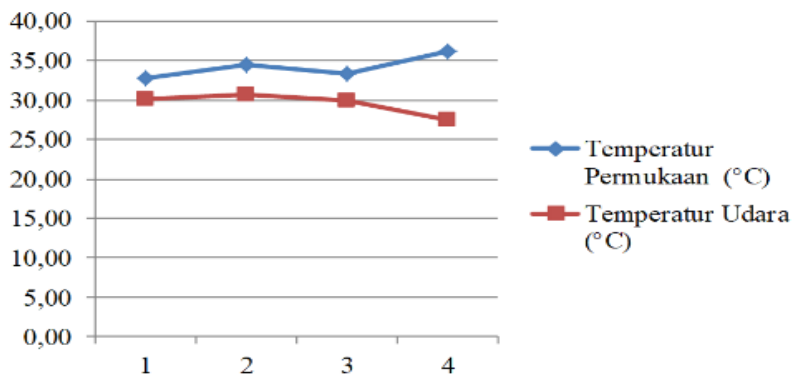

(a)

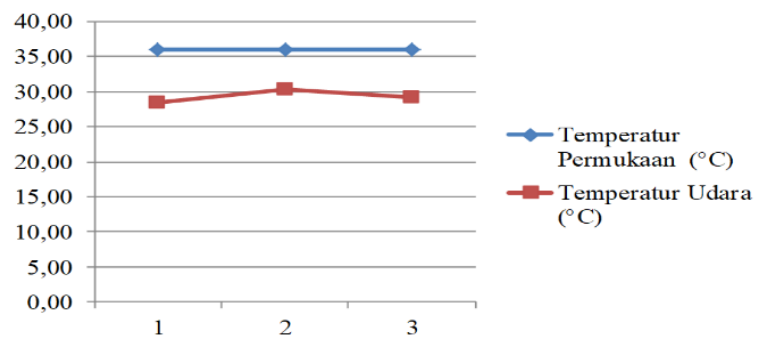

(b)

Gambar 4. Analisa temperatur udara dan temperatur permukaan pada (a) Koridor Jalan Utara-Selatan dan (b) Koridor Jalan Timur-Barat (sumber : hasil analisa, 2017) 
Jika kita mencermati hasil pengukuran pada gambar 4(b) terlihat temperatur udara tertinggi terdapat di titik pengukuran 2 , namun di permukaan material penutup jalur pedestrian tertinggi berada di titik 4. Kondisi koridor jalan, lebih khususnya jalur pedestriannya adalah komposisi antara pembayang dan lebar koridor jalan yang berbeda jauh, sehingga dengan kondisi jalan raya yang terpapar radiasi matahari pada siang hari diduga menjadi penyebab utama tingginya temperatur udara di titik ini. Hal ini hampir sama dengan yang terjadi pada titik pengukuran 1 , meskipun temperatur permukaan jalur pedestrian berada di posisi terendah dibandingkan koridor jalan yang lain. Pembayangan dari vegetasi tidak memberikan kontribusi yang signifikan dalam kasus ini.

Perbedaan temperatur yang sangat signifikan terjadi pada titik pengukuran 4 antara temperatur udara dan permukaan jalur pedestrian. Rata-rata temperatur permukaan yang tinggi hingga mencapai $36,30^{\circ} \mathrm{C}$ sangat jauh rentangnya dibandingkan temperatur udara yang rata-rata berkisar $27,57^{\circ} \mathrm{C}$, atau selisih $8,73^{\circ} \mathrm{C}$. Hal ini menunjukkan bahwa pengaruh lingkungan di sekitar area pembayangan sangatlah besar. Terdapatnya koridor area yang terbayangi selain di titik pengukuran, sirkulasi udara (angin) di koridor jalan yang merupakan koridor angin serta kombinasi jumlah dari koridor jalan yang banyak diduga mempengaruhi hasil pengukuran ini. Penyebaran melalui material jalan merambat ke area jalur pedestrian juga cukup berperan dalam menyebarkan panas material.

Jalur pedestrian yang posisinya mendekati arah Timur-Barat di Kota Pontianak memiliki pembayangan di area Utara dan Selatannya. Pembayangan dihasilkan oleh bangunan gedung yang ada di lokasi, sedangkan koridor jalan tersebut sedikit agak condong, Hal ini menjadikan area jalur pedestrian rata rata terbayangi di pagi dan sore hari, namun tidak di siang hari. Koridor jalan yang mendekati arah TimurBarat merupakan koridor jalan yang seharusnya mendekati arah lintasan matahari, namun karena agak menyerong maka terbentuk beberapa area pembayangan di setiap sisi jalannya. Kondisi koridor jalan yang demikian menjadikan terciptanya pembayangan terutama pada pagi dan sore hari. Pembayangan terbentuk oleh bangunan terutama oleh bangunan tinggi (2 lantai ke atas) atau penghijauan di tepi koridor jalan. Pengaruh pembayangan ini tentunya berkaitan antara lebar koridor jalan dibandingkan dengan ketinggian bangunan di sekitarnya.

Hal ini terlihat pada gambar 4, bahwa di titik pengukuran 1 dan 3 memiliki temperatur udara yang lebih rendah dibandingkan dengan titik pengukuran 2 . Titik pengukuran 1 dan 3 mengalami pembayangan pada pagi dan sore hari, kondisi bangunan di kedua koridor jalan tersebut sangat tinggi dibandingkan lebar koridor jalan di depannya.

Perbandingan temperatur permukaan jalur pedestrian dengan suhu udara di atasnya cukup signifikan (di atas $2^{\circ} \mathrm{C}$ ), hal ini dimungkinkan karena adanya pengaruh pergerakan udara (angin) di atasnya karena terbentuknya koridor angin yang searah dengan angin dominan. Pergerakan angin akan membawa pengaruh temperatur udara dari area lain di sekitarnya. Dengan demikian, kondisi udara di suatu area akan terpengaruh oleh kondisi udara di sekitarnya. Pergerakan udara di suatu koridor jalan sangat dipengaruhi oleh bentuk arsitektur dari bangunan di sekitarnya (Lisa \& Nova Purnama, 2017).

\section{KESIMPULAN}

Jika dibandingkan antara temperatur permukaan jalur pedestrian dengan temperatur udara di atasnya, rata - rata temperatur permukaan jalur pedestrian memiliki temperatur yang lebih tinggi. Temperatur udara yang diukur kurang lebih setinggi 1,5 meter dari pemukaan perkerasan kemungkinan dipengaruhi oleh beberapa faktor lain selain radiasi matahari yang dipengaruhi oleh pembayangan. Hal ini terjadi baik pada koridor jalan yang searah maupun yang melintang dengan lintasan matahari. Pembayangan yang terbentuk oleh vegetasi tidak memberikan pengaruh yang berbeda dibandingkan dengan pembayangan yang terbentuk karena vegetasi terhadap penurunan temperatur udara di suatu area tertentu. Penurunan temperatur udara lebih dipengaruhi oleh durasi pembayangan yang dialami oleh suatu area.

\section{REFERENSI}

Auliciems, Andris, S., \& V., S. (2007). Thermal Comfort. Queensland: Departmen of Architecture, The University of Queensland Brisbane.

Baharuddin, I., M.Taufik, B., Syarif, O., \& M.Yoenus. (2013). Analisis Kenyamanan dan Lingkungan Termal pada Ruang Kuliah dengan Ventilasi Alami (Studi Kasus: Kampus II Fakultas Teknik Unhas Gowa). Semesta Arsitektur Nusantara 2; Arsitektur Nusantara Berkelanjutan. Malang: Jurusan Arsitektur Universitas Brawijaya.

Dotulong, A. L. (2008). Pengaruh Pembayangan Massa Bangunan Terhadap Radiasi Panas Matahari Di Ruang Terbuka Kawasan Tropis Yang Terletak Pada Garis Lintang $7^{\circ} \mathrm{Ls}$. Jurnal Arsitektur \& Perencanaan ,3(1), 1-11.

Indraswara, M. S., \& Rifan, Y. (2013). Pengaruh Sistem Pembayangan Pada Bentuk Fasade Bangunan Perkantoran yang Hemat Energi (Studi Kasus Bangunan Kolonial di Kota Lama Semarang). Modul, 13(1) , 41-48.

Lippsmeier, G. (1994). Bangunan Tropis. Jakarta: Erlangga. 
Lisa, \& Nova Purnama, N. (2017). Pengaruh Adaptasi Arsitektur Tropis pada Bangunan Kolonial di Koridor Jalan Blang Mee Samudera Pase. Seminar Heritage IPLBI 2017 (pp. B111-B118). Cirebon: IPLBI.

Nikolopoulou, M., \& Lykoudis, S. (2006). Thermal Comfort in Outdoor Urban Spaces: Analysis Acroos Diferent European Countries. Building and Environment , 1455-1470.

Satwiko, \& Prasasto. (2008). Fisika Bangunan. Yogyakarta: Andi.

Sugini. (2004). Pemaknaan Istilah-Istilah Kualitas Kenyamanan Thermal Ruang Dalam Kaitan dengan Variabel Iklim Ruang. Logika , 3-17.. 